\title{
UPAYA GURU MENINGKATKAN KEMAMPUAN MEMBACA SISWA
}

\author{
Nancy Angelia Purba \\ Universitas Katolik Santo Thomas Medan, nancypurba27@gmail.com
}

\begin{abstract}
Upaya yang dimaksud disini adalah bagaimana guru mempersiapan diri dalam membelajarkan siswa mulai dari membaca cepat dan efektif, masalah yang dihadapi pembaca, beberapa pandangan yang salah terhadap membaca dan lain-lain. Bila upaya-upaya tersebut dilaksanakan dengan berorientasi pada kepentingan siswa, maka diharapkan dapat menimbulkan dan meningkatkan kemampuan membaca siswa. Banyak hal yang dapat dilakukan oleh guru sebagai upaya untuk meningkatkan kemampuan membaca siswa, tiga diantaranya: (1) mengetahui metode dan teknik membaca efektif dan efisien, (2) membentuk kebiasaan dan mengukur kemampuan membaca sendiri, (3) meningkatkan minat baca.
\end{abstract}

\section{Kata Kunci: Upaya guru, kemampuan membaca siswa}

\begin{abstract}
The effort referred to here is how the teacher prepares himself to teach students starting from speedy and effective reading, problems faced by readers, some wrong views on reading and others. If these efforts are carried out oriented towards the interests of students, they are expected to be able to give rise to and improve students' reading abilities. Many things can be done by teachers as an effort to improve students' reading skills, three of them: (1) knowing effective and efficient reading methods and techniques, (2) forming habits and measuring their own reading skills, (3) increasing reading interest.
\end{abstract}

\section{Keywords: Teacher's effort, students' reading ability}

\section{PENDAHULUAN}

Membaca adalah salah satu dari empat kemampuan bahasa pokok dan merupakan satu bagian atau komponen dari komunikasi tulisan. Membaca juga merupakan suatu proses yang dilakukan serta dipergunakan oleh pembaca untuk memperoleh pesan, yang hendak disampaikan oleh penulis melalui media kata-kata/ bahasa tulis. Suatu proses yang menuntut agar kelompok kata yang merupakan suatu kesatuan akan terliht dalam suatu pandangan sekilas, dan agar makna kata-kata secara individual akan dapat diketahui. Kalau hal ini tidak terpenuhi, maka pesan yang tersurat dan yang tersirat tidak akan tertangkap akan dipahami, dan proses membaca tidak terlaksana dengan.

Dari segi linguistik, membaca adalah suatu proses penyandian kembali dan pembacaan sandi (a recording and decoding process), berlainan dengan berbicara dan menulis yang justru melibatkan penyandian (encoding). Sebuah aspek pembacaan (decoding) adalah menghubungkan kata-kata tulis dengan makna bahasa lisan yang mencakup pengubahan tulisan/cetakan menjadi bunyi yang bermakna (Anderson 1972:209:210).

Istilah-istilah linguistik decoding dan encoding tersebut akan lebih mudah dimengerti kalau kita dapat memahami bahasa adalah sandi yang direncakan untuk membaca/mengandung makna. Kalau kita menyimak ujaran pembicara maka pada dasarnya kita men-decode (membaca sandi) makna ujaran tersebut. Apabila kita berbicara, maka pada dasarnya kita mengecode (menyandikan) bunyi-bunyi bahasa untuk membuat/mengutarakan makna. 
Seperti halnya kita berbicara dalam bentuk grafik, maka menulis pun merupakan suatu proses penyandian dan membaca suatu proses penyandian dan membaca sebagai suatu penafsiran atau interpretasi terhadap ujaran yang berada dalam bentuk tulisan adalah suatu proses pembacaan sandi.

Adapun tujuan membaca adalah untuk mencari serta memperoleh informasi, mencakup isi, memahami makna bacaan. Makna, arti erat sekali berhubungan dengan maksud tujuan, atau intensif kita membaca membaca. Beberapa hal penting dalam membaca: Pertama, membaca untuk menemukan atau mengetahui penemuanpenemuan yang telah dilakukan oleh sang tokoh, apa-apa yang telah dibuat oleh sang tokoh; Kedua, membaca untuk mengetahui mengapa hal itu merupakan topik yang baik dan menarik, masalah yang terdapat dalam cerita, apa-apa yang dipelajari atau yang dialami sang sang tokoh; Ketiga, membaca untuk menemukan atau mengetahui apa yang terjadi pada setiap bagian cerita, apa yang terjadi mula-mula pertama, kedua, dan ketiga seterusnya; Keempat, membaca untuk menemukan serta mengetahui mengapa para tokoh merasakan seperti cara mereka itu, apa yang hendak diperlihatkan oleh sang pengarang kepada para pembaca; Kelima, membaca untuk menemukan serta mengetahui apa-apa yang tidak biasa, tidak wajar mengenai seseorang tokoh, apa yang tidak biasa, tidak wajar mengenai seseorang tokoh, apa yang lucu dalam cerita, atau apakah cerita itu benar atau tidak benar; Keenam, membaca untuk menemukan apakah sang tokoh berhasil atau hidup dengan ukuran-ukuran tertentu, apakah kita ingin berbuat seperti yang diperbuat oleh sang tokoh atau bekerja seperti cara sang tokoh bekerja dalam cerita itu, Ketujuh, membaca untuk menemukan bagaimana caranya sang tokoh berubah, bagaimana hidupnya berbeda dari kehidupan yang kita kenal, bagaimana dua cerita mempunyai persamaan, bagaimana sang tokoh menyerupai pembaca.

\section{PEMBAHASAN}

Sebelum siswa merasa bahwa membaca adalah suatu kebutuhan maka guru akan susah untuk mendorong/ membangkitkan semangat membaca siswa. Oleh sebab itu, kita diharapkan untuk menjadi pembaca yang cepat dan efektif. Pertama, yang perlu diingat ialah bahwa membaca itu adalah sebuah proses yang kompleks dan rumit. Kompleks artinya adalah sebuah proses yang kompleks dan rumit. Kompleks artinya dalam proses membaca terlibat berbagai faktor internal dan faktor eksternal pembaca. Faktor internal dapat berupa intelegensi (IQ), minat, sikap, bakat, motivasi, tujuan membaca, teks bacaan. Faktor eksternal bisa dalam bentuk sarana membaca, teks bacaan (sederhana, berat, mudah-sulit), faktor lingkungan, atau faktor latar belakang sosial ekonomi, kebiasaan dan tradisi membaca.

Membaca dapat ditingkatkan dengan mengetahui metode dan teknik membaca, kemudian diikuti oleh latihan yang intensif, ditambah dengan membiasakan diri membaca dengan cepat, maka dalam beberapa minggu saja Anda akan dapat melihat hasilnya. Secara teoretis kecepatan membaca itu dapat ditingkatkan menjadi dua sampai tiga kali lipat dari kecepatan semula. Kecepatan membaca dengan 150 kata per menit dengan latihan intensif selama jangka waktu satu sampai dua bulan akan meningkat menjadi lebih dari 400 kata per menit.

Bukti yang pernah ada ialah apa yang dilakukan John A. Broyson dari Universitas Florida. Ia melatih sejumlah 111 orang untuk ditingkatkan kecepatan membacanya. Pada awal latihan, kecepatan mereka pada mulanya berkisar antara 115 - 210 menit kata per menit (sama dengan kecepatan yang memadai untuk siswa sekolah dasar), tetapi juga tiga bulan kemudian, dengan latihan yang intensif, 52 orang mampu meningkatkan kecepatan membacanya menjadi 295 - 325 kata per menit (dua sampai tiga kali lipat).

Dengan bukti yang telah ada maka sarana untuk meningkatkan kecepatan itu perlu ada. Selanjutnya yang perlu diingat adalah bahwa kecepatan dan keefektifan 
membaca (kemampuan membaca secara umum) itu bukan merupakan kemampuan bawaan. Kemampuan membaca adalah kemampuan yang merupakan hasil latihan, yang barangkali didukung pula oleh faktor bawaan tertentu. Akan tetapi, kemampuan membacanya adalah hasil dari pembiasaan dan latihan sehingga diperoleh tahap yang tinggi keefektifannya. Kebiasaan membaca sehari-hari adalah penentu dalam latihan.

Kenyataan sehari-hari menunjukkan bahwa untuk tujuan tertentu, kita perlu menggunakan kemampuan membaca cepat untuk mengambil makna bahan bacaan secara efektif dan efisien untuk mengambil makna bahan bacaan secara efektif dan efisien. Ambillah contoh ketika kita dihadapkan pada sebuah buku menarik di sebuah toko buku, sementara waktu yang tersedia terbatas, serta kantung tidak memungkinkan membeli buku tersebut. Untuk mengetahui keseluruhan isi buku secara cepat semacam ini kita perlu teknik tertentu dalam membaca cepat. Atau misalnya bila kita menghadapi ujian sekolah. Buku di meja mengggunung, sementara waktu yang ada hanya semalam. Maka dengan terpaksa kita harus membaca buku tersebut dengan cepat.

\section{Metode Kosakata}

Metode kosakata adalah metode mengembangkan kecepatan membaca melalui pengembangan kosakata. Artinya, metode ini mengarahkan perhatian pada aspek perbendaharaan kata seorang pembaca. Bagaimana caranya? Kosakata seseorang itu terbatas jumlahnya, dan akan selalu berkembang terus sesuai dengan kemampuannya menambah kosakata itu setiap hari. Latihan meningkatkan dan menambah kosa kata baru dengan cepat dan dalam jumlah yang banyak inilah metode kosakata di atas. Dasar pemikiran metode ini sudah jelas, yaitu semakin besar dan semakin banyak perbendaharaan kata seseorang, semakin tinggi kecepatan membacanya. Inilah prinsipnya.

\section{Metode Motivasi (Minat)}

Mengapa disebut metode motivasi (minat)? Aneh tampaknya. Akan tetapi, begitulah metode ini disebut orang. Cara kerjanya ialah memotivasi para pemula (pembaca yang mengalami hambatan dalam kecepatan membacanya) dengan berbagai macam rangsangan bacaan yang menarik sehingga tumbuh minat membacanya. Dari sini kemudian diharapkan muncul kebiasaan membaca tinggi, yang pada akhirnya meningkat pula kecepatan dan pemahamannya terhadap bacaan. Mengapa bisa diasumsikan demikian?

Pikiran yang mendasari lahirnya metode ini ialah semakin tertarik atau berminatnya seseorang pada jenis buku tertentu, semakin tinggi kecepatan dan pemahaman seseorang. Demikian sebaliknya, bila seseorang membaca buku yang kurang disukai, maka ia akan membaca dengan kecepatan yang rendah. Atau dengan kata lain, minat terhadap bacaan itu mempengaruhi daya baca seseorang. Oleh karena itu, saran pencipta metode ini, untuk meningkatkan kecepatan membaca anak didik, berikan motivasi dan rangsangan membaca dengan buku-buku atau bahan bacaan yang diminatinya. Akan tetapi, tampaknya, seperti metode yang pertama, metode ini tidak banyak diikuti orang, karena bukti bahwa tidak selalu kecepatan membaca yang tinggi itu disebabkan oleh daya tarik terhadap buku yang dibaca. Bisa saja terjadi bahwa seseorang membaca buku tertentu dengan kecepatan dan kecermatan yang tinggi meskipun ia kurang senang dengan buku tersebut. Yang benar mungkin ialah bahwa minat atau motivasi yang tinggi untuk membaca, akan menimbulkan kebiasaan membaca. Dan kebiasaan membaca inilah yang akan meningkatkan kecepatan dan kecermatan membaca, sedikit demi sedikit. Tak ada jeleknya pula ini diterapkan. Bukan mengikuti prinsipnya, melainkan peningkatan minat baca itulah barangkali yang lebih penting.

\section{Metode Bantuan Alat}

Metode ketiga yang pernah dikembangkan untuk meningkatakan kecepatan dan kecermatan membaca anak 
didik adalah melatih kecepatan membaca itu dengan bantuan alat. Bagaimana caranya?

Ketika seorang membaca (melihat baris-baris bacaan), gerak matanya dipercepat dengan bantuan alat yang berupa ujung pensil, ujung jari, atau alat petunju khusus dari kayu. Gerak mata dibantu oleh gerak ujung alat yang dipergunakan. Pertama dengan kecepatan rendah, kemudian dipercepat, dipercepat dan terus dipercepat. Jadi, kecepatan mata mengikuti kecepatan gerak alat.

Metode ini memperoleh hasil cukup memuaskan. Terjadi peningkatan membaca yang memadai. Akan tetapi, pada akhirnya diketaui efek negatifnya, yaitu adanya ketergantungan pada alat bantu yang digunakan. Begitu alat dihilangkan, kecepatan membaca kembali seperti semula. Dan kecenderungan yang kurang efisien bila diterapkan pada pengajaran membaca selanjutnya.

\section{Metode Gerak Mata}

Metode gerak mata adalah metode yang paling banyak dipakai dan dikembangkan orang saat ini, baik untuk pengajaran membaca permulaan, maupun saat bagi siapa yang ingin meningkatkan kecepatan membacanya. Bagaimana metode ini diterapkan? Jawabannya mudah, yaitu mengembangkan kecepatan membaca dengan meningkatkan kecepatan gerak mata. Kok bisa? Ya, karena kecepatan membaca itu sendiri berarti kecepatan gerak mata dalam menelusuri unit-unit bahasa dalam bacaan.

Metode ini mendapat sukses benar dalam meningkatkan kecepatan membaca. Selain caranya yang mudah dan dalam waktu yang relatif singkat, seseorang akan mampu meningkatkan kecepatan membacanya dua sampai tiga kali lipat. Metode inilah yang akan dikembangkan lagi.

\section{PEMBAHASAN}

\section{Membentuk Kebiasaan dan Mengukur Kemampuan Membaca Sendiri}

Kemampuan membaca ialah kecepatan membaca dan pemahaman isi bacaan. Cara mengukur kemampuan membaca ialah: Jumlah kata yang dapat dibaca per menit dikalikan dengan persentase pemahaman isi bacaan. Misalnya, jika yang dapat siswa baca permenit adalah 200 kata, dan jawaban yang benar atas pertanyaanpertanyaan isi bacaan itu adalah $60 \%$, maka kemampuan baca adalah $200 \times 60 \%=120$ kpm (kata per menit). Jika diterima bahwa lulusan SMA diharapkan mampu memiliki kemampuan membaca minimal 250 kata per menit dengan pemahaman minimum $70 \%$, maka kemampuan membaca minimum SMA lulusan SMA ialah $250 \times 70 \%=175 \mathrm{kpm}$.

Membentuk kebiasaan membaca yang efisien memakan waktu yang relative lama. Oleh karena itu, usaha-usaha pembentukan hendaklah dimulai sedini mungkin dalam kehidupan, yaitu sejak masa anak-anak. Pada masa anak-anak, usaha pembentukan dalam arti peletakan fundasi minat yang baik dapat dimulai sejak kira-kira dua tahun yaitu sesudah anak dapat mempergunakan bahasa lisan (memahami yang dikatakan dan berbicara) walaupun masih dalam taraf bahasa yang jauh dari sempurna menurut ukuran dewasa. Usaha yang dapat dilakukan pada taraf permulaan ini ialah merangsang daya visual dan motoris anak untuk sekedar mengenali buku. Anggota-anggota keluarga yang sering dilihat oleh anak membaca atau memegang buku di rumah misalnya, adalah suatu usaha yang baik dalam hal ini. Kemudian setelah anak itu bertumbuh (2 1/2 - 3 tahun) akan baik sekali pengaruhnya, jika kepada anak diberikan buku-buku bergambar, apalagi jika anak itu didorong untuk membuka bukubuku itu dan melihat gambar-gambar yang ada di dalamnya serta menyebut nama gambar-gambar itu. Pada umur 3-4 tahun, anak dapat mulai diajar mengenali tulisan, misalnya nama-nam gambar.

Setelah anak mulai sekolah dasar dan telah dapat membaca permulaan (huruf, kata dan kalimat), dia perlu semakin dirangsang untuk membuka dan membaca buku-buku yang sesuai dengan dipelajarinya di sekolah. Demikian selanjutnya dengan anak yang berada di sekolah menengah pertama dan menengah atas. 
Anak-ana setelah di sekolah, perlu sekali-sekali dibawa ke perpustakaan. Anak perlu diajak dan ditunjuki bagaimana cara di ruanga baca di perpustakaan.

Seorang sarjana pernah mengatakan bahwa orang yang membaca dengan baik adalah orang yang biasanya berpikir baik, memiliki suatu dasar pendapat dan suatu batu ujian bagi pertimbangan. Orang yang setelah buta huruf kerapkali ditandai oleh minatminat yang amat terbatas dan ruang lingkup bacaan yang terbatas. Setiap orang yang hanya membaca ruangan bagian tertentu seperti olahraga, komik, halaman perhimpunan atau seksi-seksi hiburan pada Koran harian, biasanya tidak sanggup mengikutsertakan dirinya kecuali dalam suatu percakapan yang sembrono. Hidup mereka terbuang-buang begitu saja dalam pencarian serta pengejaran hal-hal yang ngawur, hal-hal yang tidak bertalian satu sama lain.

Sebagai seorang siswa yang ingin menjadi anggota masyarakat yang dihormati serta yang bertanggung jawab maka semua harus mencurahkan perhatian serta usaha pada peningkatan minat baca. Suatu sikap ingin tahu yang intelektual, yang bijaksana, ditambah dengan usaha yang konstan untuk menggali bidang-bidang pengetahuan baru, akan menolong siswa untuk meningkatkan serta memperluas minat baca. Saran-saran, dorongan-dorongan bagi minat-minat baru datang dari orang-orang teman berbicara, pengalaman-pengalaman yang diperoleh dapat dilihat dan didengar, baik secara kontak langsung atau melalui gambar hidup televise, membaca, ataupun sumber-sumber lainnya. Orang yang teliti selalu menemui bidangbidang baru untuk digarap dan diteliti. Orang yang menghadapi apa yang telah diketahui saja akan segera menemui dirinya ketinggalan jauh di belakang teman sebayanya, teman sejawatnya, tidak menjadi soal dalam bidang apa sajapun dia berusaha.

Untuk meningkatkan minat membaca ini, maka perlu sekali siswa berusaha dalam menyediakan waktu untuk membaca dan memilih bahan bacaan yang mencakup norma-orma estetik, sastra dan moral.

\section{KESIMPULAN}

Upaya guru dalam meningkatkan kemampuan membaca siswa sudah seharusnya dibantu oleh orangtua sejak kirakira berumur dua tahun yaitu sesuah anak mulai dapat mempergunakan bahasa lisan (memahami apa yang dikatakan dan berbicara). Upaya guru di sekolah menindaklanjuti dari upaya orangtua di rumah yaitu dengan (1) mengetahui metode dan teknik membaca efektif dan efisien, (2) membentuk kebiasaan dan mengukur kemampuan membaca sendiri, meningkatkan kemampuan dan minat baca.

\section{DAFTAR PUSTAKA}

Anderson, R. C. 1972. Language Skills in Elementary Education. New York: Macmillan Publishing Co, Inc.

Tarigan, Henry Guntur. 2010. Membaca Sebagai Suatu Keterampilan Berbahasa. Bandung: Angkasa

Nurhadi. 2013. Membaca Cepat dan Efektif. Bandung: Sinar Baru.

Khalik. 2000. Pengajaran Bahasa Indonesia I. Jakarta: Depdikbud

Soedarso. 2004. Speeding Reading. Bandung: Gramedia

Dalman. 2013. Keterampilan Membaca. Jakarta: Grafindo Persada

Tampubolon. 1987. Kemampuan Membaca Teknik Membaca Efektif dan Efisien. Bandung. Angkasa 